\title{
SZEMLE
}

\section{A SPECIÁlis NEVELÉS MINT 2I. SZÁZADI IPARÁG}

\author{
SOMOGYI-ROHONCZY ZSÓFIA \\ ELTE Neveléstudományi Doktori Iskola
}

Sally Tomlinson: A Sociology of Special and Inclusive Education: Exploring the Manufacturing of Inability. London, 2017. Routledge. xiv + 182 p. ISBN: 978-1-315-64623-7

A hátrányos helyzetűek oktatása, az inklúzió bevezetése a 21 . század oktatásának egyik meghatározó kérdése. Tanulmányok, könyvek, előadások, konferenciák tömkelege foglalkozik a témával a legváltozatosabb megközelítésből. A problémát nem érdemes csak egy szakterület ismeretein keresztül megközelíteni, ez viszont nagy kihívás elé állítja a kutatókat, hiszen multidiszciplinaritást követel tőlük. Ennek a kritériumnak magas színvonalon megfelel az angol szakértő, Sally Tomlinson, aki az elmúlt harminc évben az oktatás különböző területein tett szert komplex tudásra, foglalkozott többek között etnikai és faji jellegzetességekkel, az iskola és az otthon viszonyával, a nemzetközi oktatási alapelvekkel. 2017-ben a Routledge Kiadónál megjelent A Sociology of Special and Inclusive Education címü kötetében ezeknek a témáknak nyújtja alapos áttekintését.

Könyvében Tomlinson a speciális és inkluzív nevelés komplex és többszereplős viszonyát vázolja fel olyan alapossággal és magától értetődő egyszerűséggel, mintha csak egy matematikai képletet látnánk. $\mathrm{A} z$ angolszász világ (főként Egyesült Királyság és USA) oktatását az elmúlt 150 év történeti, törvényi és elméleti hátterének felvázolásával, valamint az egyes szereplők érdekrendszerének figyelembevételével tárja elénk. A speciális nevelés működésének elemzésében túl tud lépni a nemzeti adottságokon, és rámutat arra, hogy a leírt folyamatok nem az angolszász rendszer adottságai, még csak nem is a globalizálódott világunk sajátos rákfenéje, hanem már-már ősi emberi tulajdonságokon alapszanak: az erősebb hatalmat gyakorol a gyengébbek felett, és saját haszna érdekében irányítja őket.

A kötet hét nagyobb fejezetben mutatja be a téma fontosabb szereplöit, nagy számban ismertet meghatározó kutatási és oktatáspolitikai tanulmányokat, bemutatja a föbb gondolkodókat és nevelésügyi programokat - a szociológia mellett a neurológia és a pszichológia kutatásait is érintve. Az összetett téma alapos megismerésének érdekében Tomlinson jól áttekinthető hívószavakat és kérdésköröket biztosít számunkra. A politikán, tudományon, gazdasági tényezőkön túl maguk az érdekelt csoportok (pl. a szakma képviselői, a szülök) is megjelennek Tomlinson helyzetelemzésében. 
$\mathrm{A} z$ egyik legfontosabb kérdés, amelyet a szerző (is) érint: ki tartozik a speciális igényüek csoportjába? A kötetet olvasva, a besorolás terén végbemenő változásokat szemlélve, megfogalmazódhat bennünk a válasz, hogy lényegében bárki, akit a hatalmát féltő csoport odasorolni akar. A besorolás kérdése közel sem elhanyagolható, hiszen alapjaiban határozza meg, hogy milyen intézményeket alapítanak a fejlesztés - vagy éppen az elszigetelés - érdekében. A könyv által vizsgált időszakban (a kötet erős gazdasági nézőpontjához híven az ipari forradalom időszakától napjainkig) változatos kategóriákat és megnevezéseket használtak (gyengeelméjü, rossz magaviseletű, testi fogyatékossággal élő). A kezdeti elnevezések mellé az 1900-as években a pszichológia térnyerésével egyre több kategória társul, gondoljunk csal a diszlexiára, az autizmus spektrumzavarra vagy a figyelemhiányos hiperaktivitás-zavarra (ADHD). Napjaink aggasztó tendenciája, hogy egyre több szülő kér gyermeke számára igazolást speciális igényekről annak érdekében, hogy tüneteit gyógyszerrel kezeljék, esetleg speciális iskolába kerülhessen, vagy csupán azért, hogy a család állami támogatáshoz jusson.

A stigmatizált csoportok jellemzőinek azonosítása központi téma a szakemberek számára. A fizikai vagy mentális tünetek, a család gazdasági hátterén túllépve fontos megállapításra jutott Pierre Bourdieu és Jean-Claude Passeron, akik 1977-es müvükben $^{1}$ a kulturális preferenciákat, az oktatási tőkét, a szülők hivatását és végzettségét beemelték a gyermekek hátterének változói közé. A speciális nevelést igénylők egyre fontosabb csoportját képezik a 20. század vége óta a különböző kisebbségek és a bevándorlók, akik a kö-

J. P. Bourdieu \& J. C. Passeron: Reproduction in Education, Society and Culture. London, Beverly Hills: Sage Publications, 1977. tetben bemutatott nagyszámú vizsgálat tanúsága szerint nemcsak hamar válnak SNI-ssé, de az iskolából is nagyobb arányban morzsolódnak le, a munkaerőpiacon pedig legfeljebb valamilyen alacsonyabb fizetést biztosító munkakörben tudnak elhelyezkedni.

A leghangsúlyosabb, legfontosabb szempont a fejezeteket olvasva mindig ugyanaz: a pénz. Ahogy a szerző már az első fejezet folyamán kifejti: a tömegoktatás sosem a tág értelemben vett társadalom igényeinek kiszolgálásáról szólt. Korunkban az értékes tudás - és ezzel együtt az értékes szaktudással rendelkező munkás - árucikké vált, az oktatás pedig egyre inkább státuszszimbólum. Éppen ezért nem csodálkozhatunk, hogy a tudás hatalmát birtokló csoport (felső- és középosztály) arra törekszik, hogy az alsóbb társadalmi rétegeket elszigetelje, megakadályozza a tudás általi felemelkedésben, illetve a szükséges és elvárt oktatás költségeit minél alacsonyabb szinten tartsa. Az oktatásban tehát egy olyan hatékony fegyvert ismerhetünk meg, amellyel a társadalom uralkodó csoportjai képesek hatalmat gyakorolni az alattuk elhelyezkedő társadalmi csoportok felett. Igényeiknek megfelelően vagy felemelik (iskolai inklúzió, speciális nevelés támogatása), vagy kirekesztik (speciális intézmények létesítése, törvényi szabályozás) a számukra nem hasznosnak ítélt munkaerőt.

A történeti és gazdasági kérdések között cikázva azt érezhetjük, hogy a speciális igényüek oktatása az elmúlt századok során két véglet, az inklúzió és a kirekesztés között mozgott. Fontos szétválasztani a politika által hangoztatott véleményeket és a valóságban müködő folyamatokat. Hiába támogatják a nagy nemzetközi szervezetek (UNESCO, OECD, EU, ENSZ, Világbank) a mindenkire kiterjedő oktatás céljait, a valóságban nemzeti vagy éppen intézményi szinten dől el a 
speciális nevelést igénylő gyerekek sorsa, megnövelve ezzel a szakértők képzésének és jogkörének fontosságát.

A szakértőiséghez kapcsolódik a kötet negyedik, a mérések kérdésének szentelt fejezete. A tesztek és mérések szintén kétarcú kérdésnek tekinthetők a témában. Lehetőséget biztosítanak a speciális oktatási igény minél pontosabb meghatározására, az igények megismerésére, de egyúttal felhasználhatók a kirekesztés, az egyes csoportok befeketítésére, ideológiák alátámasztására is. Szélsőséges példa Karl Pearson, aki az 1890-es évek adatai alapján készített grafikonjának harang alakú görbéjével szándékozott kapcsolatot kimutatni a szegénység és a genetikai alsóbbrendűség között. Az egyes csoportok IQ teszteredményei általi megítélése és nemegyszer hátrányos helyzetbe hozatala a későbbiekben tovább folytatódott, még akkor is, ha a módszer fejlesztése során törekedtek a megbízhatóság növelésére és a kulturális különbségek, iskoláztatás okozta torzítás kiküszöbölésére. Így például Robert Yerkes amerikai pszichológus I. világháborús katonákon végzett vizsgálataihoz külön tesztet (Alpha és Beta teszt) fejlesztett ki az írástudatlanok számára, valamint egy, a pantomimon alapuló tesztet az angolul nem beszélők számára.

$\mathrm{A} z$ IQ-tesztek az eugenika híveinek voltak kedvelt vizsgálati módszerei. (Az eugenika egyébként a negyedik fejezet másik hangsúlyos témája.) Arthur Jensen amerikai pszichológus messzemenő következtetéseket vont le a kapott eredményekből, többek között azt, hogy a súlyos mentális betegségeket génhibák okozzák, és ezek az IQ-görbe alsó végén gyakoribbnak tekinthetők. Azt, hogy a főként a náci ideológiával összekapcsolt eugenika nem történelmi emlék csupán, jól mutatja, hogy a politikai retorikában újra és újra felüti a fejét. Napjainkban az ún. új eugenika a génkutatással kapott új erőre. $\mathrm{A} z$ öröklődésbe vetett hit növelheti az iskolai szelekciót és szeparációt, sok kriminológus bizonyítékot lát benne a szegény és kisebbségi csoportok alacsonyabbrendüségére.

Genetikai kutatásokra napjainkban súlyos pénzösszegeket költenek, meghatározó gazdasági tényezővé váltak. Így fordíthatott például Robert Plomin amerikai viselkedéskutató, a londoni King's College munkatársa fontmilliókat ikerkutatásaira. Ugyanakkor Bruce Perry 2002-ben publikált felvételeit is több ízben említi a szerző, amelyeken jól látható, hogyan igyekeznek tudományos vizsgálatokkal a környezeti hatásokat igazolni. Így például két hároméves gyerek agyáról készült felvételt az amerikai akadémikus annak bizonyítékaként tekintette, hogy az elhanyagolás súlyos károkat okoz a korai fejlődési szakaszban. Ezzel összefüggésben gazdasági összefüggéseket is azonosított: a korai beavatkozás jelentős szociális és gazdasági költségeket spórolhat meg a társadalomnak.

A könyvben megjelennek az IQ-tesztek megbízhatóságát vitató vélemények is. A szerző ennek jegyében mutatja be James Flynn megfigyeléseit, aki kimutatta, hogy az 1930-as évektől minden évtizedben nőttek az IQ-tesztek átlagértékei. Feltehetnénk a kérdést, hogy vajon tényleg okosabbak vagyunk, mint nagyszüleink vagy éppen az antik görögök? Természetesen nem, inkább arról lehet szó - ahogy erre az új-zélandi kutató is rávilágít -, hogy a mai gyerekeket az iskola jobban felkészíti a tesztek kitöltésére, ráadásul a környezetük is stimulálóbb. John Geake ennél is továbbmegy. Az IQ-tesztek vizsgálata során kimutatta, hogy az elmúlt évtizedek alatt az absztraktprobléma-megoldó képesség fejlődött, nem pedig az általános intelligencia, ezt a kutató a számítógépek használatának fejlesztő hatásának tulajdonítja.

A család fogyasztóként is megjelenik Tomlinson rendszerében - mint speciális 
nevelési szolgáltatást igénybe vevő társadalmi egység. Attól függően, hogy milyen anyagi és intellektuális tartalékokkal rendelkezik, az oktatás révén más és más jövőt biztosít a gyermek számára. A társadalmi megosztottság, az eltérő lehetőségek itt is megjelennek: míg az arisztokrácia annak élete végéig meg tudta védeni rászoruló gyermekét, addig a munkásosztály utódait speciális iskolákban különítették el és olcsó munkaerőként kezelték. A helyzet az elmúlt száz évben sem változott jelentősen, a 21. század szülője éppúgy gondban lehet, ha speciális igényű gyermeke jövőjéről szeretne gondoskodni. Az információk és jó tanácsok áradatában a szülők nem kapnak jelentősebb támogatást, megfelelő segítséget, sőt a legtöbb hivatalos megközelítés a szülőket egységes tömegként kezeli, jóllehet, kulturális és anyagi hátterük, családi állapotuk, világnézetük, gyermekük adottságai alapján valójában egy rendkívül sokszínü csoportról kellene beszélni. Az iskola és szülő közötti jó együttmüködés vélhetőleg már itt megbukik, illetve csak abban az esetben müködhet megfelelően, ha a szülők önérdek-érvényesítése, öngon- doskodása életbe tud lépni, és az egyre növekvő frusztrációjuk, a megbélyegzéstől való félelmük ellenére részt mernek vállalni az iskolatanácsokban, és közreműködnek az oktatási alapelvek kialakításában.

A felvázolt szempontok talán érzékeltetik a bemutatott összetett rendszer föbb kapcsolódási pontjait, illetve müködésének alapvető törvényszerüségeit. Sally Tomlinson olyan érzékeny és folyamatosan változó mechanizmust mutat be, amely erőteljesen támaszkodik a társadalom aktuális állapotára, a gazdaság igényeire és a politikában megfogalmazott narratívákra. A kötet az angolszász terület oktatási rendszerének keretében mutatja be az inklúzió eddigi történetét és jelen állapotát, de még a magyar szakemberek számára is fontos kiindulási alap lehet. Leginkább a szemléletmódja és árnyalt megközelítése ajánlható, amely hozzájárulhat ahhoz, hogy a politika és a gazdaság számára adatokként megjelenő elemek (gyerekek, szülők, szakemberek) egyéni jellemzőkkel gazdagodjanak az elemzések során.

A cikk a Creative Commons Attribution 4.0 International License (https://creativecommons.org/licenses/ by-nc/4.0/) feltételei szerint publikált Open Access közlemény, melynek szellemében a cikk bármilyen médiumban szabadon felhasználható, megosztható és újraközölhető, feltéve, hogy az eredeti szerző és a közlés helye, illetve a CC License linkje és az esetlegesen végrehajtott módosítások feltüntetésre kerülnek. 